\title{
Socio-demographic, Clinical and Microbiological Study of Sexually Transmitted Infections in a Tertiary Care Hospital of South India
}

\author{
Haritha Thiruveedhula ${ }^{1}$, K. Sushma Chowdary ${ }^{2}$, G. Venkateswara Rao ${ }^{3}$ \\ and Sri Ranjitha Galla ${ }^{4}$ \\ Department of DVL, NRI Medical College \& General Hospital, Chinakakani, \\ Mangalagiri Mandal, Guntur Distirct, Andhra Pradesh, India \\ *Corresponding author
}

\begin{abstract}
A B S T R A C T
Keywords

Sexually Transmitted Infections (STIs), Mixed STI infection, Candidiasis, Non gonococcal cervcitis / urethritis, Human Immunodeficiency Virus (HIV).

\section{Article Info}

Accepted: 18 April 2016 Available Online: 20 May 2016

Sexually Transmitted Infections (STIs) are a major public health challenge in India. In addition to the physical and psychological consequences of STIs, these diseases also exact a tremendous economic toll. To study the socio-demographic, clinical and microbiological characteristics among patients attending the STI clinic of a tertiary care hospital of South India from January 2014 to March 2016 (26 months). A retrospective analysis was done by obtaining data from the predesigned STI case records. The majority of patients were females $(63.8 \%)$ and belonged to young age group and upper lower socioeconomic class. The most common STI was mixed infection (35.7\%) seen most commonly in females (vaginal / cervical discharge syndrome), followed by candidiasis (30.7\%), herpes genitalis (12.6\%), condylomata acuminata (6.5\%). Mixed infections were most frequently caused by Trichomoniasis (83.1\%), Candidiasis (73.2\%), Bacterial vaginosis $(50.7 \%)$ and Non gonococcal cervicitis/ urethritis (30.98\%). Prevention programs, active screening strategies and better access to STI diagnosis and treatment services are necessary to reduce the incidence and the burden of STIs.
\end{abstract}

\section{Introduction}

STIs are major global and national health priorities. They have devastating impact on the health of women and infants. Unnoticed and untreated STIs can lead to Pelvic Inflammatory Disease (PID) in women, infertility in both sexes, ectopic pregnancy, problems during pregnancy such as abortions, fetal deaths, low birth weight babies and health problems for the unborn baby. Infection with high-risk HPV if undetected and untreated can cause cervical cancer (STDs and Pregnancy, 2008; Aral et al., 2006). STIs also increase the risk for transmission of the human immunodeficiency virus (HIV) (Cohen, 2012; Lewis, 2012).

To ensure country-level planning and effective local implementation of STI services, reliable and consistent epidemiologic information is required about the distribution of STI cases, rate and trends 
of newly acquired infections, and STI prevalence in specific population groups.

\section{Methods}

In this retrospective study conducted at a tertiary care hospital of South India, the predesigned STI case records of all patients attending STI clinic during a 26 months period (January 2014 to March 2016) were analyzed. A detailed history was taken; socio-demographic data (including the age, sex, occupation, marital status, and education), complaints and their duration, past STI symptoms, history of sexual behavior and history of a similar illness in the sexual partner were recorded on printed proformas. After clinical examination, urethral swab from males, and vaginal \& cervical swabs were collected from females and subjected to examination after Gram's staining, Wet mount, $\mathrm{KOH}$ mount and Tzanck smear. All patients were tested for HIV by ELISA after due consent. In patients with clinical suspicion of syphilis, serology for Venereal Disease Research Laboratory test (VDRL) was done. The diagnosis was made based on clinical history, examination, and laboratory investigations. The following results were noted.

\section{Results and Discussion}

Out of the total 199 patients included in the study, 63.8\% (127/199) were females, $36.2 \%(72 / 199)$ were males with female to male ratio being 1.8:1(Table 1).

The majority of patients belonged to the age group 21-30 years - 40.7\% (81/199), followed by the $31-40$ years - $27.15 \%$ $(54 / 199)$. In the <21 years age group, all were females except for one male patient (Table 1).

In our study, $55.3 \%$ of patients had completed middle school education and $24.6 \%$ were illiterates (Table 2). We found that $55.3 \%$ belonged to upper lower class according to modified Kuppuswamy's Socio-economic scale (Table2).

Out of the total, 90.5\% (180/199) were married and 9.5\% (19/199) were unmarried (Table 3). Of those married twelve were widowed and six were either living separately from their spouses or were divorced. $21 \%$ of patients practiced risky sexual behaviour, $15 \%$ of all males had been exposed to commercial sex workers. $7 \%$ of all females gave history of spouse practicing risky sexual behaviour. Condoms reduce the risk of acquiring STIs but condom use is inconsistent, noted in $4 \%$ of male patients (Table 4).

The most common STI was mixed infection (35.7\%) seen most commonly in females presenting with vaginal / cervical discharge syndrome, followed by candidiasis (30.7\%), herpes genitalis (12.6\%), condylomata acuminata $(6.5 \%)$, molluscum contagiosum $(3.5 \%)$ bacterial vaginosis $(2 \%)$, trichomoniasis (2\%), non-gonococcal cervicitis $(1 \%)$, gonococcal urethritis $(1 \%)$, genital ulcer disease non-herpetic $(1 \%)$ in decreasing order. Venereophobia was noted in $4 \%$ of patients, who were all males (Table $5)$.

The vast majority of these patients with multiple STIs were females $(88.7 \%)$. Trichomoniasis $\quad(83.1 \%), \quad$ Candidiasis (73.2\%), Bacterial vaginosis $(50.7 \%)$ and Non gonococcal cervicitis / urethritis (30.98\%) were most frequently associated with multiple STIs (Table 6). VDRL testing was done in 27 patients with clinical suspicion of syphilis, out of whom none were reactive. Out of the total 199 patients, $10.5 \%$ (21/199) were found to be HIV positive, in which $38 \%(8 / 21)$ were males and $62 \%(13 / 21)$ were females. In our study, females outnumbered the males in the ratio 
of 1.8:1. Male preponderance has been reported by some authors. (Ray et al., 2006; Narayanan, 2005) However, more females accessing the STI clinics has been noted by others (Ganju, 2012; Goel et al., 2012).

Table.1 Age and Sex distribution of Sexually Transmitted Infection patients $(n=199)$

\begin{tabular}{|c|c|c|c|c|}
\hline \multirow{2}{*}{ Age in years } & \multicolumn{2}{|c|}{ No. Of STI patients } & \multirow{2}{*}{ Total } & \multirow{2}{*}{ Percent } \\
\cline { 2 - 3 } & Male & Female & & \\
\hline $12-20$ & 1 & 17 & 18 & 9.05 \\
\hline $21-30$ & 23 & 58 & 81 & 40.7 \\
\hline $31-40$ & 29 & 25 & 54 & 27.15 \\
\hline $41-50$ & 8 & 19 & 27 & 13.6 \\
\hline$>50$ & 11 & 8 & 19 & 9.5 \\
\hline
\end{tabular}

Table.2 Sociodemographic Status of Sexually Transmitted Infection Patients ( $n=199)$

\begin{tabular}{|l|c|c|}
\hline \multicolumn{1}{|c|}{ Status } & $\begin{array}{c}\text { No. Patients } \\
(\text { n=199 })\end{array}$ & Percent \\
\hline Education & 49 & 24.6 \\
\hline Illiterate & 22 & 11.05 \\
\hline Primary school & 18 & 9.05 \\
\hline Middle school & 66 & 33.2 \\
\hline Secondary school & 44 & 22.1 \\
\hline Graduate & \multicolumn{2}{l|}{} \\
\hline Socioeconomic status* & 28 & 14.1 \\
\hline Upper middle class & 50 & 25.1 \\
\hline Lower middle class & 110 & 55.3 \\
\hline Upper lower class & 11 & 5.5 \\
\hline Lower class & \multicolumn{2}{l|}{} \\
\hline Occupation & 80 & 40.2 \\
\hline House wife & 32 & 16.1 \\
\hline Labourer & 20 & 10.05 \\
\hline Trader & 17 & 8.54 \\
\hline Government employee & 15 & 7.53 \\
\hline Clerk & 7 & 3.5 \\
\hline Farmer & 8 & 4.02 \\
\hline Mechanic, tailor, barber, painter & 8 & 4.02 \\
\hline Student & 6 & 3.02 \\
\hline Auto/truck driver & 6 & 3.02 \\
\hline Retired & & \\
\hline
\end{tabular}

*According to modified Kuppuswamy's socioeconomic scale.

Table.3 Marital Status of Sexually Transmitted Disease Patients $(\mathrm{n}=199)$

\begin{tabular}{|l|c|c|c|c|}
\hline Marital status & Male & Female & Total & Percent \\
\hline Married & 60 & 120 & 180 & 90.5 \\
\hline Unmarried & 12 & 7 & 19 & 9.5 \\
\hline
\end{tabular}


Table.4 Sexual behaviour in sexually transmitted infection patients $(n=199)$

\begin{tabular}{|l|c|c|}
\hline \multicolumn{1}{|c|}{ Sexual Behaviour } & Male & Female \\
\hline $\begin{array}{l}\text { Contact with commercial sex } \\
\text { workers (CSWs) }\end{array}$ & 30 & 0 \\
\hline Contact with known person & 0 & 5 \\
\hline Use of barrier contraception & 8 & 0 \\
\hline $\begin{array}{l}\text { Spouse with premarital and } \\
\text { extramarital exposures }\end{array}$ & 0 & 14 \\
\hline Bisexual contact & 3 & 0 \\
\hline
\end{tabular}

Table.5 Pattern of sexually transmitted infections $(\mathrm{n}=199)$

\begin{tabular}{|l|c|c|l|}
\hline \multicolumn{1}{|c|}{ STI } & $\begin{array}{c}\text { No. female } \\
\text { patients }\end{array}$ & $\begin{array}{c}\text { No. male } \\
\text { patients }\end{array}$ & \multicolumn{1}{c|}{$\begin{array}{c}\text { Total } \\
(\%)\end{array}$} \\
\hline $\begin{array}{l}\text { Candidiasis (Vulva Vaginal Candidiasis in } \\
\text { female and candidal balanoposthitis in male) }\end{array}$ & 29 & 32 & $61(30.7 \%)$ \\
\hline Herpes genitalis & 10 & 15 & $25(12.6 \%)$ \\
\hline Condylomata acuminate & 8 & 5 & $13(6.5 \%)$ \\
\hline Molluscum contagiosum & 6 & 1 & $7(3.5 \%)$ \\
\hline Trichomoniasis & 4 & & $4(2 \%)$ \\
\hline Bacterial vaginosis (BV) & 4 & & $4(2 \%)$ \\
\hline Non-gonococcal urethritis/cervicitis & 2 & & $2(1 \%)$ \\
\hline Gonococcal urethritis & 1 & 1 & $2(1 \%)$ \\
\hline Genital ulcer disease non-herpetic & & 2 & $2(1 \%)$ \\
\hline Mixed infections & 63 & 8 & $71(35.7 \%)$ \\
\hline Venereophobia & & 8 & $8(4 \%)$ \\
\hline
\end{tabular}

Table.6 Frequency of different sexually transmitted infections in the multiple infections group

\begin{tabular}{|l|c|c|}
\hline \multicolumn{1}{|c|}{ Mixed Infection $(\mathbf{n = 7 1 )}$} & Frequency & Percentage \\
\hline Trichomoniasis & 59 & 83.1 \\
\hline Candidiasis & 52 & 73.2 \\
\hline Bacterial vaginosis & 36 & 50.7 \\
\hline $\begin{array}{l}\text { Non gonococcal } \\
\text { cervicitis/urethritis }\end{array}$ & 22 & 30.98 \\
\hline Genital ulcer disease-Herpetic & 11 & 15.5 \\
\hline Gonococcal urethritis & 2 & 2.8 \\
\hline Molluscum contagiosum & 2 & 2.8 \\
\hline Lymphogranuloma venereum & 1 & 1.4 \\
\hline
\end{tabular}


In the present study, highest number of patients $(40.7 \%)$ was seen in the age group of 21-30 years. This is also the predominant age group observed to be having STI in other Indian studies ( Devi et al., 2009; Saikia et al., 2009; Jain et al., 2008). 55.3\% of all our patients had completed middle school education and $55.3 \%$ belonged to upper lower class according to modified Kuppuswamy's Socio-economic scale. Similar findings were reported by Saikia L et al., 2009.

In the present study, proportion of STIs was significantly higher in housewives $(40.2 \%)$, followed by labourers $(16.1 \%)$ and traders $(10.05 \%)$.

The majority of our patients were married (90.5\%). $16.7 \%$ of the total males, while only $5.5 \%$ of total number of females were unmarried.

Sexual behaviour among STI patients in our study is similar to that reported by Singh et al. (2008).

In our study, $35.7 \%$ of the patients had more than one concurrent STIs. Similar observation has been made by Choudhry $\mathrm{S}$ et al.,(13) study. Trichomoniasis (83.1\%), Candidiasis $(73.2 \%)$, Bacterial vaginosis $(50.7 \%)$ and Non gonococcal cervicitis / urethritis (30.98\%) were most frequently associated with multiple STIs. These findings are contrary to the report of Choudhry S et al. (2010).

In the present study, the prevalence of HIV among STI patients was $10.5 \%$ (females $62 \%$, males $-38 \%$ ) with female to male ratio being 1.6:1. There was a wide variation for seropositivity for HIV among STI patients, $8.21 \%$ in Zamzachin et al., (2003) study, 9.62\% in Jaiswal et al., (2002) study, 17.2\% in Saikia et al., (2009) study, and $10.3 \%$ in Choudhry et al., (2010) study.
The burden of disease caused by STI and HIV on a nation, varies widely, both within and between different countries. Prompt administration of effective therapy for STIs reduces transmission of HIV by reducing the duration of a biological cofactor for HIV transmission, which can lead to decreased infectiousness in an HIV positive person or decreased susceptibility in an HIV negative person. By continuous surveillance of STI cases, changing trends can be traced, leading to identification of highly affected gruops. This helps in redesigning preventive strategies, with the goal of finding the most effective way to reach these highly affected population groups.

Imparting sex education in high schools, lower socio-economic groups is recommended. Information, Education and Counselling (IEC) techniques on safe sex, condom usage, restriction to single partner, targeting the high risk groups such as commercial sex workers, recognition of early symptoms of STIs will further decrease the risk of STI transmission.

\section{Acknowledgements}

We sincerely thank our retired Professor and HOD, Dr. R. Subba Rao, M. D., without whose help this work would not have been made possible, Dr. G. Srinivas, M. D., lab technician Mrs. Madhavi Bapatla, counsellor Mrs. Ch. Neelima.

\section{References}

Aral, S.O., Over, M., Manhart, L., Holmes, K.K. 2006. Disease Control Priorities in Developing Countries. In Sexually Transmitted Infections. 2nd edition. Edited by Jamison DT, Breman JG, Measham AR, Alleyne G, Claeson M, Evans DB, Jha P, Mills A, Musgrove P. Washington (DC): World Bank. 
Choudhry, S., Ramachandran, V.G., Das, S., Bhattacharya, S.N., Mogha, N.S. 2010. Pattern of sexually transmitted infections and performance of syndromic management against etiological diagnosis in patients attending the sexually transmitted infection clinic of a tertiary care hospital. Indian J. Sex Transm. Dis., 31: 104-8.

Cohen, M.S. 2012. Classical sexually transmitted diseases drive the spread of HIV-1: back to the future. J. Infect. Dis., 206(1): 1-2.

Devi, S.A., Vetrichevvel, T.P., Pise, G.A., Thappa, D.M. 2009. Pattern of sexually transmitted infections in a tertiary care centre at Puducherry. Indian $J$. Dermatol., 54: 347-9.

Ganju, S.A., Sharma, N.L. 2012. Initial assessment of scaled-up sexually transmitted infection intervention in Himachal Pradesh under National AIDS Control Program - III. Indian J. Sex Transm. Dis., 33: 20-4.

Goel, S.S., Goel, S.S. 2012. Study of syndromic management approach in the management of sexually transmitted diseases in rural population. Indian $J$. Sex Transm. Dis., 33: 146-7.

Jain, V.K., Dayal, S., Aggarwal, K., Jain, S. 2008. Changing trends of sexually transmitted diseases at Rohtak. Indian J. Sex Transm. Dis., 29: 23-5.

Jaiswal, A.K., Banerjee, S., Matety, A.R., Grover, S. 2002. Changing trends in sexually transmitted diseases in North
Eastern India. Indian J. Dermatol. Venereol. Leprol., 68: 65-6.

Lewis, D.A. 2012. Detection and management of acute HIV infections in patients with sexually transmitted infections: a window of opportunity for HIV prevention within South Africa? South Afr. J. Epidemiol. Infect., 27(4): 149-155.

Narayanan, B. 2005. A retrospective study of the pattern of sexually transmitted diseases during a ten-year period. Indian J. Dermatol. Venereol. Leprol., 71: 3337.

Ray, K., Bala, M., Gupta, S.M., Khunger, N., Puri, P., Muralidhar, S., et al. Changing trends in sexually transmitted infections at a regional STD Centre in North India. Indian J. Med. Res., 124: 559-68.

Saikia, L., Nath, R., Deuori, T., Mahanta, J. 2009. Sexually transmitted diseases in Assam: An experience in a tertiary care referral hospital. Indian $J$ Dermatol. Venereol. Leprol., 75: 329.

Singh, N., Kaimal, S., Thappa, D.M. 2008. Sexual behavior of clinic attendees in a tertiary care hospital in Pondicherry. Indian J. Sex Transm. Dis., 29: 18-22.

STDs and Pregnancy - CDC Fact Sheet. Center for Disease Control. 2008.

Zamzachin, G., Singh, N.B., Devi, T.B. 2003. STD trends in regional institute of medical sciences, Manipur. Indian $J$. Dermatol. Venereol. Leprol., 69: 151-3.

\section{How to cite this article:}

Haritha Thiruveedhula, K. Sushma Chowdary, G. Venkateswara Rao and Sri Ranjitha Galla. 2016. Socio-demographic, Clinical and Microbiological Study of Sexually Transmitted Infections in a Tertiary Care Hospital of South India. Int.J.Curr.Microbiol.App.Sci.5(5): 674679. doi: http://dx.doi.org/10.20546/ijcmas.2016.505.068 